\title{
Role of Different Salmonella enterica Serotypes in THP-1 Macrophage-Derived Foam Cell Autophagy and Inflammatory Response
}

(Peranan Serotip Berbeza Salmonella enterica pada Tindak Balas Sel Buih THP-1 Makrofaj Terbitan Autofagi dan Inflamasi)

\author{
Min Yi Wong, YuAN-Hsi Tseng, Tsung-Yu HuANG, CHENG-HSUn CHIU, \\ CHYI-LIANG CHEN \& YAO-KUANG HUANG*
}

\begin{abstract}
Infected aortic aneurysm is a rare but life-threatening condition. Intimal injury, especially in arteries with atherosclerotic plaques, is vulnerable to Salmonella species. In this study, THP-1 macrophage-derived foam cells were used to mimic the atherosclerotic plaques. We investigated the role of different Salmonella serotype infections in foam cell autophagy and inflammatory response. Three different serotypes of Salmonella enterica-Typhimurium, Enteritidis, and Choleraesuis with or without a virulence plasmid were used in this study. The foam cell model was established and observed under confocal microscopy. The expression of autophagy and inflammasome-related proteins after Salmonella infection was detected by Western blotting, and the secretion of the proinflammatory cytokines interleukin-1 $\beta$ and IL-18 was detected using ELISA. The plasmid-bearing S. enteritidis OU7130- and plasmid-less S. choleraesuis ou7266-infected foam cells both showed a lower expression of beclin-1 at 0.5 h post-infection (hpi) and p62 at 2 hpi as well as a higher expression of caspase-1 at 2 hpi than other infected cells. Moreover, infection of ou7266 induced the highest IL-1 $\beta$ and IL-18 production among the tested strains. In conclusion, the virulence plasmid of S. enteritidis ou7130 induced foam cell inflammatory responses, whereas that of $\mathrm{S}$. choleraesuis played an opposite role. The different serotype of Salmonella may impact the infected aortic aneurysms through regulating inflammatory balance of the macrophage and foam cells in the atherosclerotic plaque.
\end{abstract}

Keywords: Autophagy; foam cells; Salmonella serotypes; virulence plasmid

\section{ABSTRAK}

Aneurisma aortik yang terjangkit adalah keadaan yang jarang berlaku namun boleh mengancam nyawa. Kecederaan intimal, terutamanya dalam arteri dengan plak atherosklerosis, terdedah kepada spesies Salmonella. Dalam kajian ini, sel buih yang berasal daripada makrofaj THP-1 digunakan untuk meniru plak aterosklerotik. Kami mengkaji peranan jangkitan serotip Salmonella yang berbeza dalam autophagia sel buih dan tindak balas keradangan. Tiga serotip Salmonella enterica - Typhimurium, Enteritidis dan Choleraesuis-dengan atau tanpa kevirulenan plasmid digunakan dalam kajian ini. Model sel buih telah ditubuhkan dan diperhatikan di bawah mikroskopi konflik. Ekspresi protein yang berkaitan dengan autofagia dan inflamasom selepas jangkitan Salmonella dikesan oleh blot Western, dan rembesan sitokin proinflamasi interleukin-1 $\beta$ dan IL-18 dikesan menggunakan ELISA. Pembekuan plasmid S. enteritidis OU7130-dan selsel buih yang dioksida S. choleraesuis oU7266 kedua-duanya menunjukkan ungkapan beclin-1 yang lebih rendah pada 0.5 jam selepas jangkitan (hpi) dan p62 pada 2 hpi serta ungkapan kaspase-1 yang lebih tinggi pada 2 hpi daripada sel yang dijangkiti yang lain. Tambahan pula, jangkitan OU7266 mendorong kepada pengeluaran tertinggi IL-1 $\beta$ dan IL-18 dalam kalangan strain yang diuji. Sebagai kesimpulan, kevirulenan plasmid S. enteritidis ou7130 bertindak balas dengan keradangan sel busa, sedangkan S. choleraesuis memainkan peranan yang bertentangan. Serotip Salmonella yang berlainan boleh memberi kesan kepada aneurisma aortik yang dijangkiti melalui mengawal keseimbangan radang makrofaj dan buih di plak aterosklerotik.

Kata kunci: Autofagi; kevirulenan plasmid; sel buih; serotip Salmonella

\section{INTRODUCTION}

Macrophage-derived foam cells play a critical role in atherosclerosis, which is a chronic inflammatory disorder characterized by the accumulation of excessive cholesterol in the arterial intima (Moore \& Tabas 2011; Yu et al. 2013). In the early stages of atherosclerosis, macrophages are differentiated from monocytes; then, they accumulate modified low-density lipoproteins and/or oxidized lowdensity lipoproteins (oxLDLs) and transform into lipidladen foam cells. The formation of macrophage foam cells, which is promoted by oxLDL in the arterial intima, is a hallmark of the development of atherosclerosis (Bobryshev 2006; Yu et al. 2013). Danger signals such as oxLDL induce the activation of the NOD-like receptor family pyrin 
domain-containing 3 (NLRP3) inflammasome, leading to caspase- 1 activation and interleukin (IL)-1 $\beta$ maturation and secretion (Liu et al. 2014).

Autophagy is a self-protecting cellular catabolic pathway that plays an essential physiological role in human health. It is associated with the initiation and development of many diseases, including cardiovascular diseases, malignant tumors, neurodegenerative diseases, and immunological diseases (Shao et al. 2016). It plays a protective role in atherosclerosis in which it promotes cholesterol efflux from the foam cells, thereby contributing to the regression of atherosclerotic plaques (De Meyer et al. 2015). In autophagy, a double-membrane structure, autophagosome is formed, which sequesters cytoplasmic cargo and subsequently fuses with lysosomes, thus facilitating sequestered cargo degradation (Kuballa et al. 2012). Beclin-1 protein plays an essential role in the critical step of autophagosome formation in autophagy (Kuballa et al. 2012). In addition, autophagy is an important defense mechanism with numerous autophagy related (ATG) proteins and autophagy adaptors involved, the host autophagy flux could be influenced by the interaction between pathogens and them. Once infected with Salmonella, autophagy can be induced rapidly which plays a pivotal role in the elimination of bacteria and the process of autophagy can even affect the following innate and adaptive immune responses to pathogens (Wang et al. 2018).

Salmonella is now considered to consist of two species, Salmonella bongori and Salmonella enterica, and $S$. enterica is further classified into six subspecies (Grimont \& Weill 2007). To date, more than 2600 serovars belonging to a highly diverse species $S$. enterica have been described worldwide, and many of these serovars are capable of causing illnesses in both humans and animals (Jajere 2019; Mezal et al. 2014). In humans, the outcome of infection with $S$. enterica depends primarily on the infecting serotype. The role of virulence plasmid of Salmonella in the outcome of infection in humans is still contentious. There is evidence supporting the view that it is necessary to cause systemic infection, but there are also studies pointing towards systemic infections caused by Salmonella strains lacking virulence plasmid (Silva et al. 2017).

Nontyphoidal Salmonellae (NTS) are Gram-negative bacteria that primarily cause infection in humans, such as enteric fever, acute gastroenteritis, bacteremia, and local infections that may occur at any site, including aneurysms. The most common isolated serotype responsible for NTS infections worldwide was $S$. enteriditis, followed by $S$. typhimurium. Most patients with a Salmonella-infected aneurysm have preexisting atherosclerosis at the site (Cohen et al. 1978; Oskoui et al. 1993). S. enterica particularly has a strong predilection to infect damaged or abnormal arterial intima, especially arteries harboring atherosclerotic plaques (Fernández-Guerrero et al. 2004). However, Salmonella has also been reported to invade normal arterial intima in the presence of atherosclerosis
(Meerkin et al.1995). Thus, to investigate the induction of foam cell autophagy and inflammasome-related proteins during infection of different Salmonella serotypes, we established foam cells to mimic atherosclerosis and demonstrated foam cell autophagy and inflammasome activation during infection with different Salmonella serotypes - Typhimurium, Enteritidis, and Choleraesuis.

\section{MATERIALS AND METHODS}

\section{REAGENTS AND ANTIBODIES}

Phorbol myristate acetate (PMA, cat. \# P8139) was purchased from Sigma-Aldrich, St. Louis, MO. Dil-conjugate oxLDL (Dil-oxLDL, cat. \# L34358) and DAPI were purchased from Invitrogen. Unlabeled oxLDL (cat. \#BT-910) was purchased from Biomedical Technologies Inc. The following antibodies were used in this study: beclin-1 mouse mAb (cat. \#4122, Cell Signaling Technology), p62 Ab (cat. \#5114, Cell Signaling Technology), caspase-1 rabbit mAb (cat. \#3866, Cell Signaling Technology), lysosome associated membrane protein-1 (LAMP-1) rabbit mAb (cat. \#9091, Cell Signaling Technology), $\beta$-actin (Abcam), NLRP3 mAb (cat. \# MA5-23919, ThermoFisher Scientific), goat anti-mouse IgG-HRP(cat. \#sc-2005, Santa Cruz Biotechnology), goat anti-rabbit IgG-HRP (cat. \#sc2006, Santa Cruz Biotechnology), and goat anti-rat IgG Alexa Fluor 647 (cat. \#A-21247, ThermoFisher Scientific).

\section{BACTERIAL STRAINS AND GROWTH CONDITION}

The bacterial strains used in this study (Table 1) were wild-type strains of S.enterica ser. Typhimurium OU5045, S. enterica ser. Enteritidis OU7130, and S. enterica ser. Choleraesuis OU7085 with 90-, 60-, and 50-kb virulence plasmids, respectively. We also used the following strains without a virulence plasmid: S. typhimurium OU5046, $S$. enteritidis OU7067, and S.choleraesuis OU7266. All strains were routinely grown on xylose lysine deoxycholate agar plates, and each colony was grown in Luria-Bertani (LB) broth at $37^{\circ} \mathrm{C}$ for $16 \mathrm{~h}$.

\section{CELL CULTURE AND DIFFERENTIATION}

The monocyte-like THP-1 cell line was obtained from the Bioresource Collection and Research Center, Taiwan. The cells were grown in RPMI 1640 medium (Sigma-Aldrich, R6504) supplemented with $10 \%$ fetal bovine serum (Sigma-Aldrich), 2 mM L-glutamine (Sigma-Aldrich, G7513), 1\% penicillin, and streptomycin (Sigma-Aldrich, $\mathrm{P} 0781)$. The cells were cultured in a $37^{\circ} \mathrm{C}, 5 \% \mathrm{CO}_{2}$, and $70 \%$ humidity incubator; the culture medium was renewed every 3-4 days. Furthermore, THP- 1 cells were treated with $200 \mathrm{nM}$ PMA and allowed to stand at $37^{\circ} \mathrm{C}$ and $5 \% \mathrm{CO}_{2}$ for 2 days following chemical differentiation into macrophages. For preparing foam cells used in confocal imaging to trace the oxLDL uptake, the differentiated THP-1 cells were treated with $10 \mu \mathrm{g} / \mathrm{mL}$ of Dil-oxLDL for $3.5 \mathrm{~h}$, whereas 
TABLE 1. Different serotypes of Salmonella strains used in this study

\begin{tabular}{|c|c|c|}
\hline Serovars & Strains & Characteristics of virulence plasmid \\
\hline \multirow{2}{*}{ S.typhimurium } & OU5045 & With a $90-\mathrm{kb}$ pSTV as a wild type \\
\hline & OU5046 & Without pSTV from wild type \\
\hline \multirow{2}{*}{ S.enteritidis } & OU7130 & With a $60-\mathrm{kb}$ pSEV as a wild type \\
\hline & OU7067 & Without pSEV from wild type \\
\hline \multirow{2}{*}{ S. choleraesuis } & OU7085 & With a $50-\mathrm{kb}$ pSCV as a wild type \\
\hline & OU7266 & Without pSCV from wild type \\
\hline
\end{tabular}

the foam cells used for Western blotting were treated with $50 \mu \mathrm{g} / \mathrm{mL}$ of unlabeled oxLDL for $24 \mathrm{~h}$.

\section{Salmonella INFECTION}

For Western blotting, a single colony of Salmonella was inoculated into $5 \mathrm{~mL}$ of $\mathrm{LB}$ broth at $37^{\circ} \mathrm{C}$ for $16 \mathrm{~h}$, and the overnight culture was subcultured for $3 \mathrm{~h}$. The THP1-derived macrophages and foam cells were treated with RPMI medium containing exponentially grown bacteria at a multiplicity of infection of 5:1, which was present in 24-well plates. Uninfected foam cells were used as a negative control. After incubation for 0.5 and $2 \mathrm{~h}$ at $37^{\circ} \mathrm{C}$, the cells were harvested by centrifugation at $4^{\circ} \mathrm{C}$ for 5 min. The cells were then washed three times with PBS and harvested by scraping for further protein extraction. For cytokines IL-1 $\beta$ and IL-18 analysis, a single colony of Salmonella was inoculated into $5 \mathrm{~mL}$ of LB broth at $37^{\circ} \mathrm{C}$ for $16 \mathrm{~h}$. The THP-1-derived foam cells were treated with RPMI medium containing stationary grown bacteria at a multiplicity of infection of 10:1, which was present in 24-well plates. Uninfected foam cells were used as a negative control. After incubation for 3 and $6 \mathrm{~h}$ at $37^{\circ} \mathrm{C}$, the culture supernatants were collected by centrifugation for ELISA detection.

\section{PROTEIN EXTRACTION AND WESTERN BLOTTING}

The cells were treated with RIPA buffer $(150 \mathrm{mM} \mathrm{NaCl}$, $20 \mathrm{mM}$ Tris- $\mathrm{HCl} \mathrm{pH}: 7.5,1 \%$ Triton $\mathrm{X}-100,1 \% \mathrm{NP}-40$, $0.1 \%$ sodium dodecyl sulfate, and $0.5 \%$ deoxycholate) on ice for $15 \mathrm{~min}$ and sonicated three times for $2 \mathrm{~s}$. After centrifugation at $4^{\circ} \mathrm{C}, 15,000 \times \mathrm{g}$ for $15 \mathrm{~min}$, the supernatant was collected and stored at $-30^{\circ} \mathrm{C}$ until used for Western blotting. Protein concentrations of the resultant supernatants were determined using the Pierce BCA protein assay kit (Thermo Scientific). Protein samples were separated electrophoretically through $12 \%$ SDS-PAGE and subsequently transferred to polyvinylidene difluoride (PVDF) membranes. For immunoblotting, the membranes were blocked with $5 \%$ skimmed milk in TBS containing $0.1 \%$ Tween 20 (TBST) for $1 \mathrm{~h}$. The membranes were then incubated at $4{ }^{\circ} \mathrm{C}$ overnight with the primary antibody against beclin-1, p62, caspase-1, LAMP-1, or $\beta$-actin. After washing five times with TBST, a secondary antibody, goat anti-rabbit IgG-HRP or goat anti-mouse IgG-HRP, was applied for $1 \mathrm{~h}$. After five TBST washes of $5 \mathrm{~min}$ each, blots were incubated in commercial ECL reagents (GE Healthcare Life Sciences) and exposed to a photographic film. The experiments were performed in triplicate and presented as mean $\pm \mathrm{SD}$.

\section{CYTOKINE DETERMINATION}

The quantitative determination of IL-1 $\beta$ (arigo Biolaboratories, ARG80101) and IL-18 (arigo Biolaboratories, ARG80138) in culture supernatants was performed using ELISA according to the manufacturer's protocol. The experiments were performed in triplicate and presented as mean \pm SD.

\section{IMMUNOFLUORESCENCE STAINING}

The Dil-oxLDL-treated THP-1 foam cells were seeded on Millicell ${ }^{\circledR}$ EZ Slides (Millipore) and infected with Salmonella. The infected THP-1 foam cells were fixed with $4 \%$ paraformaldehyde for $10 \mathrm{~min}$ and permeabilized in $0.1 \%$ Triton X-100 for 15 min. After three PBS washes for $5 \mathrm{~min}$ each, the cells were incubated with anti-NLRP3 at $4{ }^{\circ} \mathrm{C}$ overnight in a humidified chamber. After three PBS washes for 5 min each, the cells were stained with goat antirat IgG Alexa Fluor 647 and DAPI for $1 \mathrm{~h}$ in a humidified chamber. After three PBS washes for 5 min each, the cells were mounted with the Prolong Gold mounting reagent (Invitrogen). Confocal imaging was performed using the Leica SP5 II confocal microscope.

\section{STATISTICAL ANALYSIS}

Statistical analysis of the protein expression was performed using GraphPad Prism version 5.01 for Windows (GraphPad Software, La Jolla, California, USA, www.graphpad.com). Mean values between strains were compared using one-way ANOVA, followed by Tukey's multiple comparison tests. $P$ values less than 0.05 were considered significant.

\section{RESULTS}

\section{ESTABLISHMENT OF THE FOAM CELL MODEL}

We established the foam cell model for which THP-1 macrophages were transformed into foam cells through uptake of Dil-oxLDL (Figure 1). The labeled oxLDL was 


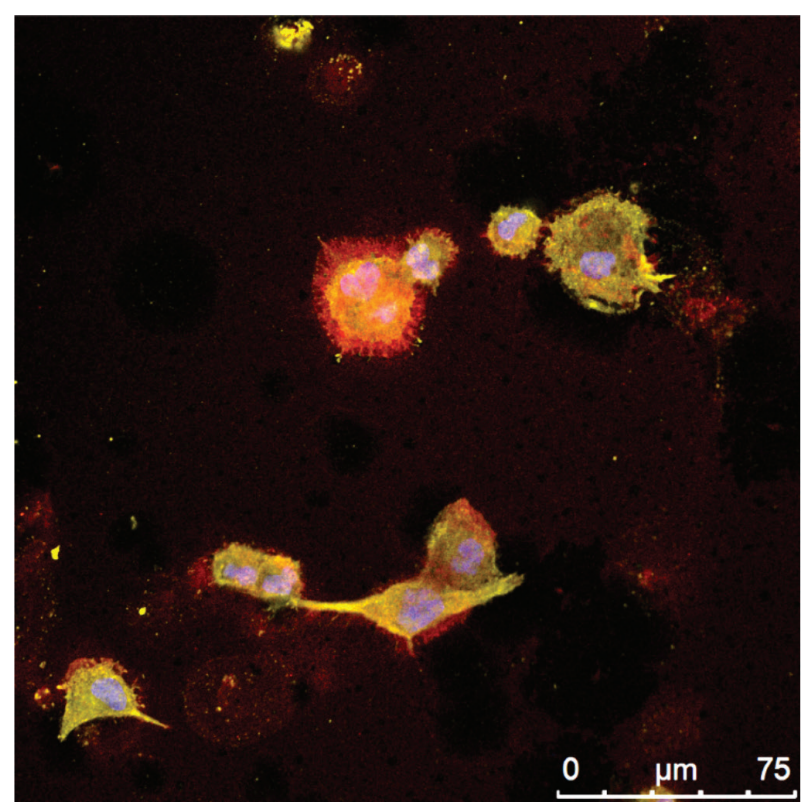

FIGURE 1. Representative image of the THP-1 macrophagederived foam cell model detected by confocal microscopy. The differentiated macrophages were treated with Dil-oxLDL (red) to form foam cells. The foam cells were infected with Salmonella enteritidis OU7130, fixed, and labeled with antiNLRP3 showing yellow cytoplasm and blue nuclei

used to observe the uptake of oxLDL, and the unlabeled oxLDL was used in further investigation of protein expression.

PLASMID-BEARING S. enteritidis AND PLASMID-LESS S. choleraesuis INDUCED LOWER BECLIN-1 PROTEIN LEVEL

We determined autophagosome formation during infection with different Salmonella serotypes by investigating the beclin-1 expression level of Salmonella-infected foam cells. Plasmid-bearing S. enteritidis OU7130 and plasmidless $S$. choleraesuis ou7266 induced lower beclin-1 expression than plasmid-less S. enteritidis OU7067 and plasmid-bearing $S$. choleraesuis OU7085, respectively, at 0.5 h post-infection (hpi) (Figure 2(A) \& 2(B)); however, beclin-1 expression in ou7130- and ou7266-infected cells was slightly increased at 2 hpi. Moreover, beclin- 1 expression in foam cells after OU7130 and OU7085 infections was significantly lower than that in uninfected cells; however, no difference was observed between $S$. typhimurium OU5045- and OU5046-infected foam cells and uninfected cells. During the induction of autophagosome formation, the virulence plasmid of ou7130, unlike that of S. choleraesuis OU7085, may have blocked autophagosome formation in the early stages of infection.

The autophagic adaptor p62 binds to ubiquitinated substrates and microtubule-associated protein 1 light chain 3 (LC3) on autophagosomes (Watanabe \& Tanaka 2011). To further explore the effect of Salmonella infection on autophagic flux, we investigated p62 levels after infection. The p62 levels in S.enteritidis- and S. choleraesuis-infected cells were significantly lower than those in uninfected cells at 2 hpi (Figure $2(\mathrm{~A}) \& 2(\mathrm{C}) ; * P<0.05$, OU7085 vs. NC; $* * P<0.005$, OU7130 vs. NC; $* * * P<0.001$, OU7266 vs. $\mathrm{NC})$. Decreased p62 expression indicated the occurrence of autophagy. The plasmid-bearing S.enteritidis OU7130infected foam cells showed slightly lower p62 levels than the plasmid-less strain OU7067. By contrast, the plasmidless $S$. choleraesuis Ou7266-infected foam cells showed slightly lower p62 levels than the plasmid-bearing strain OU7085.

Connection of caspase-1, IL-1 $\beta$, and IL-18 with Salmonella infection The activation of multiprotein complex inflammasomes after cellular infection or stress triggered caspase- 1 activation and the maturation of proinflammatory cytokines IL-1 $\beta$ and IL-18 to engage innate immune defenses (Schroder \& Tschopp 2010). To determine the involvement of different Salmonella serotypes infection in caspase-1 activation, we investigated the expression of caspase-1 after Salmonella infection for different time points. Plasmid-bearing S. enteritidis OU7130 and plasmidless $S$. choleraesuis OU7266 induced significantly higher caspase-1 expression in foam cells than did plasmid-less S.enteritidis OU7067 and plasmid-bearing S.choleraesuis OU7085, respectively, at 2 hpi (Figure 2(A) \& 2(D)).

Of the proinflammatory caspases, caspase- 1 is responsible for the conversion of the inactive proform of IL- $1 \beta$ and IL-18 to active cytokine. Thus, we determined IL-1 $\beta$ and IL-18 production using ELISA and found a similar trend as in caspase- 1 expression after $S$.enteritidis and S. choleraesuis infections (Figure 3). Plasmid-less $S$. choleraesuis OU7266 highly induced IL-1 $\beta$ and IL18 secretion. However, plasmid-bearing $S$. entertidis OU7130 induced slightly higher IL-1 $\beta$ and IL-18 secretion than plasmid-less strain ou7067. The infection of $S$. typhimurium did not affect the IL-1 $\beta$ and IL-18 secretion. These results indicated that the virulence plasmid of $S$. enteritidis is possibly involved in caspase- 1 activation and $\mathrm{IL}-1 \beta$ maturation during infection, whereas the virulence plasmid of S. choleraesuis may play an opposite role.

No correlation of Salmonella infection with LAMP-1 expression during autophagy LAMP-1 is a major protein component of the lysosomal membrane. To determine whether infection with different Salmonella serotypes was correlated with lysosomes in the autophagy pathway, we investigated LAMP-1 expression after infection. At 0.5 and $2 \mathrm{hpi}$,Salmonella-infected foam cells showed no difference from uninfected foam cells in LAMP-1 expression (Figure 2(A) \& 2(E)). These results suggested that the infection of Salmonella with or without the virulence plasmid did not affect lysosomes in the autophagy pathway.

\section{DISCUSSION}

Salmonella is one of the most common pathogens causing infected aortic aneurysm (IAA) by having a predilection for damaged blood vessels, especially those damaged 


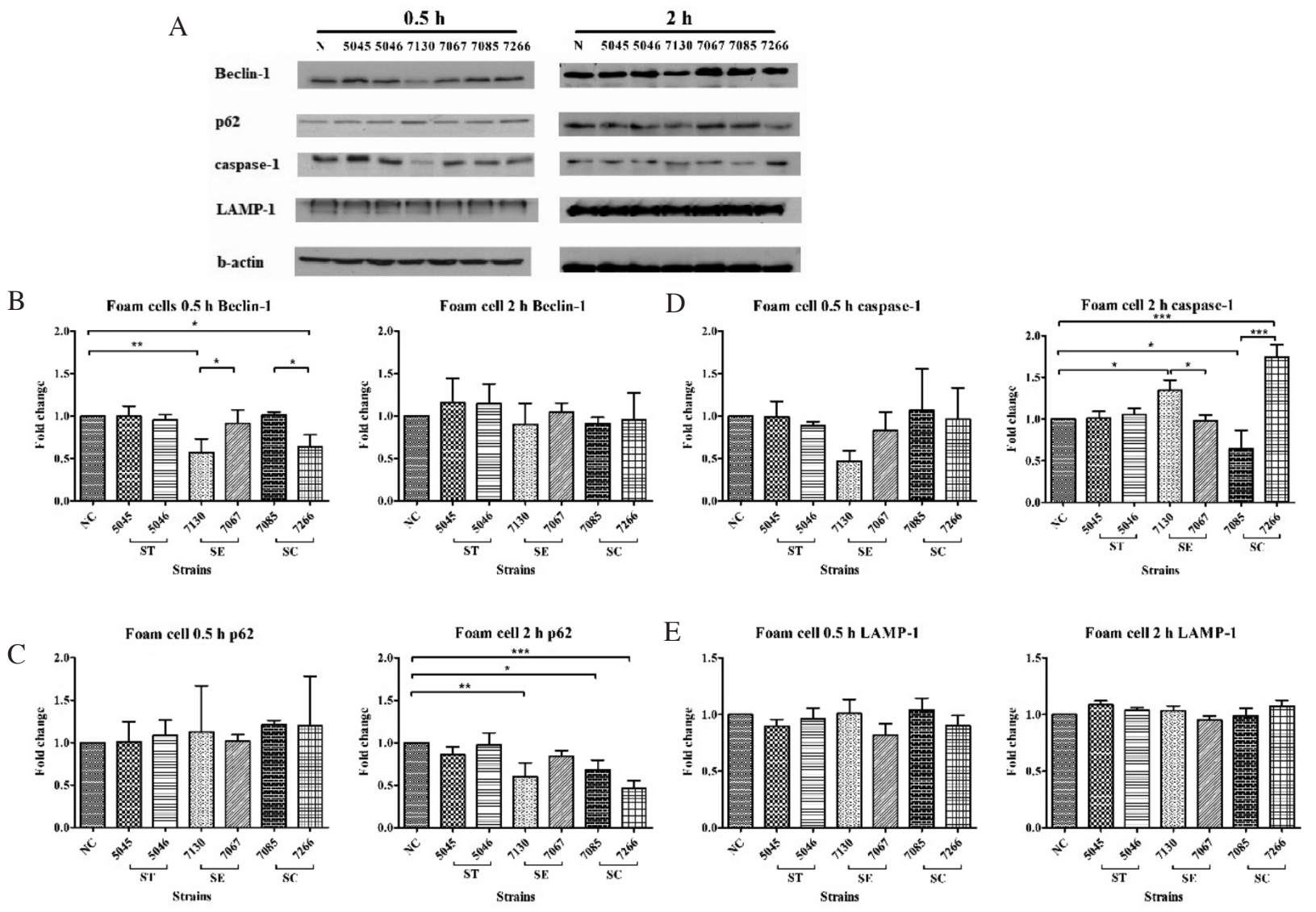

FIGURE 2. Expression of beclin-1, p62, caspase-1, and LAMP-1 proteins after Salmonella infection in THP-1 macrophage-derived foam cells. (A) Western blot analyses were performed with anti-beclin-1, anti-p62, anti-caspase-1, and anti-LAMP-1. $\beta$-actin Western blots were used as loading controls. Foam cells were infected by different serotypes of Salmonella with or without the virulence plasmid for 0.5 (left) and $2 \mathrm{~h}$ (right). Uninfected foam cells were used as a negative control. The (B) beclin-1, (C) p62, (D) caspase-1, and (E) LAMP-1 bands were quantified, and the fold change in protein expression after Salmonella infection was calculated from the ratio of infected cells relative to uninfected cells. The experiments were performed in triplicate and presented as mean $\pm \mathrm{SD} .(* P<0.05 ; * * P<0.005 ; * * * P<0.001$, one-way ANOVA). NC: uninfected cells;

ST: S.typhimurium; SE: S. enteritidis; SC: S. choleraesuis

by atherosclerosis (Salzberger et al. 2002). The most common Salmonella serotypes associated with IAAs are Typhimurium, Enteritidis, and Choleraesuis (Huang et al. 2014). Salmonella, which differs from other IAArelated pathogens, reside in the phagosomes of the host macrophages and other antigen-presenting cells.

Foam cells are a rich source of proinflammatory mediators and play a central role in inflammation in all phases of the atherosclerotic process, including the activation of proinflammatory cytokines. In this study, we investigated foam cell autophagy and inflammasomerelated protein expression along with proinflammatory cytokine secretion after infection with different Salmonella serotypes. The virulence plasmid of S. enteritidis OU7130 enhanced caspase- 1 activation and induced slightly higher IL-1 $\beta$ and IL-18 secretion, whereas that of plasmid-bearing S. choleraesuis OU7085 did not. In contrast, the virulence plasmid-less $S$. choleraesuis ou7266 induced the highest caspase- 1 activation, IL- $1 \beta$ and IL-18 secretion than other strains did.
Autophagy is a highly regulated process and plays a vital role in innate immunity to bacterial infection. p62 is a polyubiquitin chain-binding protein that is involved in the autophagy pathway and ubiquitin-proteasome system (Liu et al. 2016). The p62 level is used to monitor autophagic flux, which inversely correlates with autophagic activity (Mizushima \& Yoshimori 2014). In this study, p62 levels in different Salmonella-infected foam cells were similar to those of uninfected foam cells at 0.5 hpi. Nevertheless, the decreased p62 levels in $S$. enteritidis OU7130- and S.choleraesuis OU7266-infected foam cells at 2 hpi suggested that p62 was primarily degraded by infection-induced autophagy. However, because p62 levels can also be changed independent of autophagy (Mizushima \& Yoshimori 2014), this does not rule out the possibility of proteasomal degradation. The levels of beclin-1 in S. enteritidis OU7130- and S. choleraesuis OU7266-infected foam cells were significantly lower than those in uninfected foam cells at $0.5 \mathrm{hpi}$; this indicates that the bacterial infection 
A

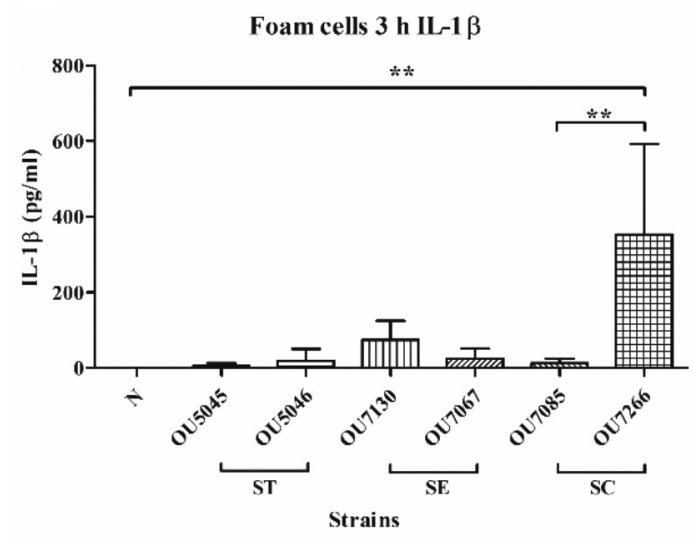

$\mathrm{C}$

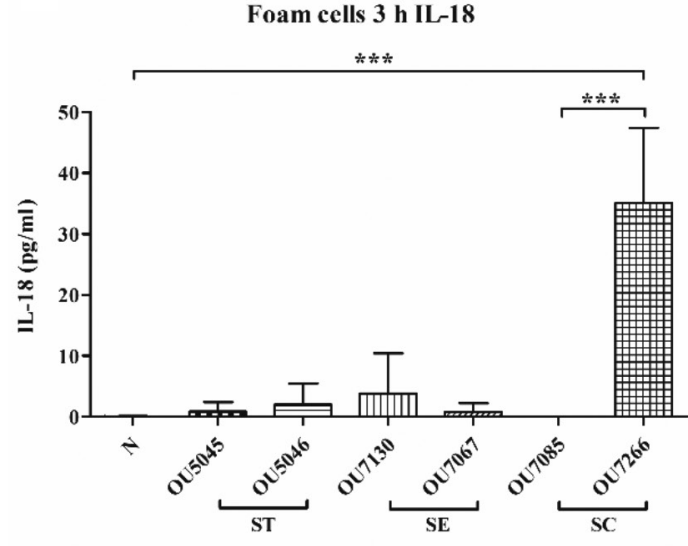

B

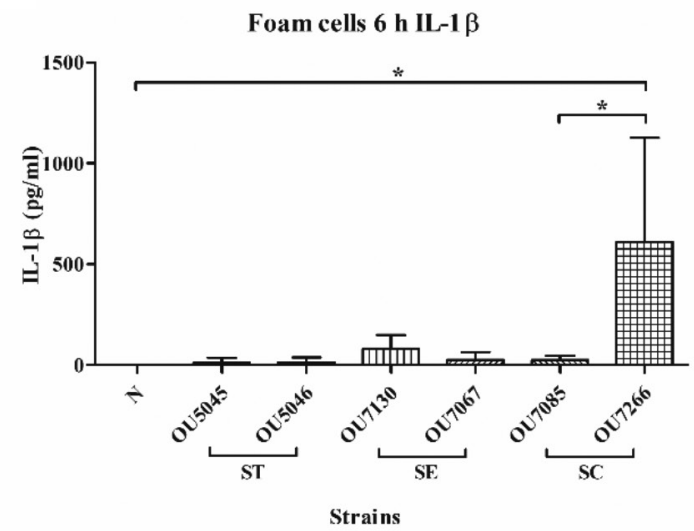

$\mathrm{D}$

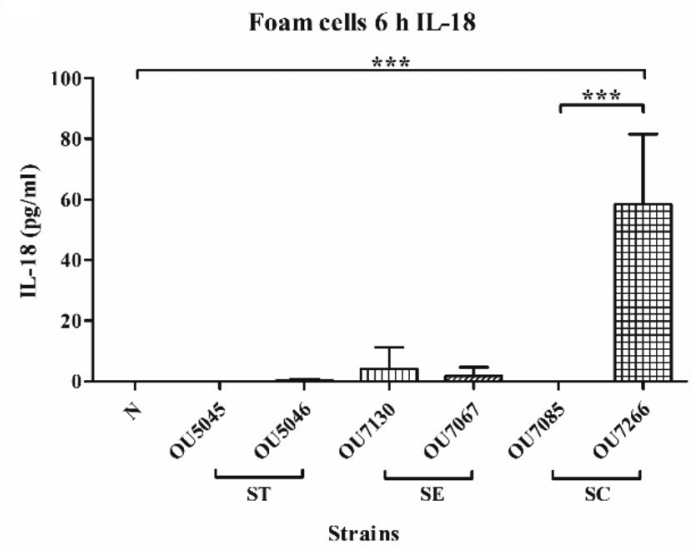

FIGURE 3. IL-1 $\beta$ production by THP-1 macrophage-derived foam cells after Salmonella infection. ELISA was performed for IL-1 $\beta$ and IL-18 produced after infection by different Salmonella serotypes. Foam cells were infected by Salmonella with or without virulence plasmids for 3 and $6 \mathrm{~h}$, and the supernatants were harvested and used for experiments. The experiments were performed in triplicate and presented as mean $\pm \mathrm{SD} .(* P<0.05 ; * * P<0.005 ; * * * P<0.005$, one-way ANOVA). NC: uninfected cells; ST: $S$. typhimurium; SE: S. enteritidis; SC: S. choleraesuis

suppressed the autophagic activity in the early stage of infection.

Inflammasomes are molecular platforms activated by infection and stress that regulate caspase- 1 activation and the maturation of proinflammatory cytokines such as IL-1 $\beta$ to engage innate immune defenses (Guo et al. 2015; Schroder \& Tschopp 2010). Moreover, NLRP3 inflammasome-driven inflammatory responses contribute to the progression of atherosclerosis (Duewell et al. 2010; Usui et al. 2012). In this study, S. enteritidis ou7130 and $S$. choleraesuis ou7266 activated caspase- 1 at 2 hpi and OU7266 triggered the high production of IL-1 $\beta$ and IL-18 at 3 hpi and 6 hpi. This suggests that the virulence plasmid of S. enteritidis is involved in the activation of the inflammasome and inflammation during the progression of atherosclerosis. By contrast, the plasmid-less $S$. choleraesuis with higher caspase- 1 activation, IL- $1 \beta$ and IL-18 maturation than the plasmid-bearing strain indicated that the virulence plasmid inhibited inflammation.

\section{STUDY LIMITATIONS}

This is an in vitro study without in vivo certification. The findings in this study could provide possible associations between Salmonella infection and atherosclerotic aortic aneurysms, however, those findings are not feasible for clinical application.

\section{CONClusion}

In conclusion, our results show that the virulence plasmid of Salmonella caused different inflammatory responses after infection: Plasmid-bearing S. enteritidis induced more IL-1 $\beta$ and IL-18 release than did its plasmid-less strain, whereas plasmid-bearing $S$. choleraesuis induced less IL- $1 \beta$ and IL-18 release than did its plasmid-less strain.

\section{ACKNOWLEDGEMENTS}

This study was supported by grants from Chang Gung Memorial Hospital, Chiayi, Taiwan (grant numbers: 
CMRPG6E0423, CMRPG6G0101, and CMRPG6H0121). We thank Wallace Academic Editing for editing this manuscript. We would like to acknowledge the Leica SP5 II confocal microscope service (support) provided by the Precious Instrumentation Core Laboratory, Chang Gung Memorial Hospital, Chiayi.

\section{REFERENCES}

Bobryshev, Y.V. 2006. Monocyte recruitment and foam cell formation in atherosclerosis. Micron 37(3): 208-222.

Cohen, P.S., O'brien, T.F., Schoenbaum, S.C. \& Medeiros, A.A. 1978. The risk of endothelial infection in adults with Salmonella bacteremia. Annals of Internal Medicine 89(6): 931-932.

De Meyer, G.R., Grootaert, M.O., Michiels, C.F., Kurdi, A., Schrijvers, D.M. \& Martinet, W. 2015. Autophagy in vascular disease. Circulation Research 116(3): 468-479.

Duewell, P., Kono, H., Rayner, K.J., Sirois, C.M., Vladimer, G., Bauernfeind, F.G., Abela, G. S., Franchi, L., Nunez, G., Schnurr, M., Espevik, T., Lien, E., Fitzgerald, K.A., Rock, K.L., Moore, K.J., Wright, S.D., Hornung, V. \& Latz, E. 2010. NLRP3 inflammasomes are required for atherogenesis and activated by cholesterol crystals. Nature 464(7293): 1357-1361.

Fernández-Guerrero, M.L., Aguado, J.M.,Arribas, A., Lumbreras, C. \& de Gorgolas, M. 2004. The spectrum of cardiovascular infections due to Salmonella enterica. Medicine 83(2): 123-138.

Grimont, P.A. \& Weill, F.X. 2007. Antigenic formulae of the Salmonella serovars. WHO Collaborating Centre for Reference and Research on Salmonella 9: 1-166.

Guo, H., Callaway, J.B. \& Ting, J.P. 2015. Inflammasomes: Mechanism of action, role in disease, and therapeutics. Nature Medicine 21(7): 677-687.

Huang, Y.K., Ko, P.J., Chen, C.L., Tsai, F.C., Wu, C.H., Lin, P.J. \& Chiu, C.H. 2014. Therapeutic opinion on endovascular repair for mycotic aortic aneurysm. Annals of Vascular Surgery 28(3): 579-589.

Jajere, S.M. 2019. A review of Salmonella enterica with particular focus on the pathogenicity and virulence factors, host specificity and antimicrobial resistance including multidrug resistance. Veterinary World 12(4): 504-521.

Kuballa, P., Nolte, W.M., Castoreno, A.B. \& Xavier, R.J. 2012. Autophagy and the immune system. Annual Review of Immunology 30: 611-646.

Liu, W., Yin, Y., Zhou, Z., He, M. \& Dai, Y. 2014. OxLDLinduced IL-1 beta secretion promoting foam cells formation was mainly via CD36 mediated ROS production leading to NLRP3 inflammasome activation. Inflammation Research 63(1): 33-43.

Liu, W.J., Ye, L., Huang, W.F., Guo, L.J., Xu, Z.G., Wu, H.L., Yang, C. \& Liu, H.F. 2016. p62 links the autophagy pathway and the ubiqutin-proteasome system upon ubiquitinated protein degradation. Cellular \& Molecular Biology Letters 21: 29.

Meerkin, D., Yinnon, A.M., Munter, R.G., Shemesh, O., Hiller, N.\& Abraham, A.S.J.C. 1995. Salmonella mycotic aneurysm of the aortic arch: Case report and review. Clinical Infectious Diseases 21(3): 523-528.

Mezal, E.H., Sabol, A., Khan, M.A., Ali, N., Stefanova, R. \& Khan, A.A. 2014. Isolation and molecular characterization of Salmonella enterica serovar Enteritidis from poultry house and clinical samples during 2010. Food Microbiology 38: $67-74$

Mizushima, N. \& Yoshimori, T. 2014. How to interpret LC3 immunoblotting. Autophagy 3(6): 542-545.

Moore, K.J. \& Tabas, I. 2011. Macrophages in the pathogenesis of atherosclerosis. Cell 145(3): 341-355.

Oskoui, R., Davis, W.A. \& Gomes, M.N.J.A. 1993. Salmonella aortitis: A report of a successfully treated case with a comprehensive review of the literature. Archives of Internal Medicine 153(4): 517-525.

Salzberger, L.A., Cavuoti, D. \& Barnard, J. 2002. Fatal Salmonella aortitis with mycotic aneurysm rupture. The American Journal of Forensic Medicine and Pathology 23(4): 382-385.

Schroder, K. \& Tschopp, J. 2010. The inflammasomes. Cell 140(6): 821-832.

Shao, B.Z., Han, B.Z., Zeng, Y.X., Su, D.F. \& Liu, C. 2016. The roles of macrophage autophagy in atherosclerosis. Acta Pharmacologica Sinica 37(2): 150-156.

Silva, C., Puente, J.L. \& Calva, E. 2017. Salmonella virulence plasmid: Pathogenesis and ecology. Pathogens and Disease. https://doi.org/10.1093/femspd/ftx070.

Usui, F., Shirasuna, K., Kimura, H., Tatsumi, K., Kawashima, A., Karasawa, T., Hida, S., Sagara, J., Taniguchi, S. \& Takahashi, M. 2012. Critical role of caspase-1 in vascular inflammation and development of atherosclerosis in Western diet-fed apolipoprotein E-deficient mice. Biochemical and Biophysical Research Communications 425(2): 162-168.

Wang, L., Yan, J., Niu, H., Huang, R. \& Wu, S. 2018. Autophagy and ubiquitination in Salmonella infection and the related inflammatory responses. Frontiers in Cellular and Infection Microbiology 8: 78.

Watanabe, Y. \& Tanaka, M. 2011. p62/SQSTM1 in autophagic clearance of a non-ubiquitylated substrate. Journal of Cell Science 124(16): 2692-2701.

Yu, X.H., Fu, Y.C., Zhang, D.W., Yin, K. \& Tang, C.K. 2013 Foam cells in atherosclerosis. Clinica Chimica Acta 424: 245-252.

Min Yi Wong, Yuan-Hsi Tseng \& Yao-Kuang Huang* Division of Thoracic and Cardiovascular Surgery

Chiayi Chang Gung Memorial Hospital

Puzi City, Chiayi County 613, and College of Medicine

Chang Gung University, Taoyuan City 333

Taiwan (R.O.C.)

Tsung-Yu Huang

Division of Infectious Diseases

Department of Internal Medicine

Chang Gung Memorial Hospital

Chang Gung University College of Medicine

Taoyuan City 333

Taiwan (R.O.C.)

Cheng-Hsun Chiu \& Chyi-Liang Chen

Molecular Infectious Disease Research Center

Chang Gung Memorial Hospital

Taoyuan City 333

Taiwan (R.O.C.) 
Cheng-Hsun Chiu

Division of Pediatric Infectious Diseases

Department of Pediatrics

Chang Gung Children's Hospital and Chang Gung University

Taoyuan City 333

Taiwan (R.O.C.)
*Corresponding author; email: yaokuang@gmail.com

Received: 22 January 2019

Accepted: 12 September 2019 